\title{
SILICON RELEASE FROM HYDROXYAPATITES IN WATER AND SIMULATED BODY FLUID
}

\section{OANA CADAR ${ }^{a}$, PETRE T. FRANGOPOL ${ }^{b}$, GHEORGHE TOMOAIA $^{c, d}$, DANIEL OLTEAN ${ }^{\mathrm{c}}$, GERTRUD A. PALTINEAN ${ }^{\mathrm{b}}$, AURORA MOCANU ${ }^{\mathrm{b}}$, OSSI HOROVITZ ${ }^{b}$, MARIA TOMOAIA-COTISEL ${ }^{b, d}$ *}

\begin{abstract}
Nanostructured hydroxyapatite (HAP) and silicon substituted hydroxyapatites (HAP-Si), with 0.47 and $2.34 \mathrm{wt} \% \mathrm{Si}$, were prepared by wet precipitation method. Their structure was investigated by $X$ rays diffraction (XRD), FTIR spectroscopy, energy dispersive $\mathrm{X}$ ray (EDX) spectroscopy and their images were obtained by TEM, SEM and AFM. Their behavior in water and SBF was investigated by inductively coupled plasma optical emission spectrometry (ICP-OES) for an immersion time from 1 to 90 days. While $\mathrm{Ca}$ and $\mathrm{P}$ release from HAP is very low, the presence of $\mathrm{Si}$ enhances greatly their release in water, along with a continuous and long lasting Si release. In simulated body fluid, SBF, Ca, P and Mg are removed from the solution, by the formation of a new HAP enriched in Mg, while silicon is released as in water. Thus, Si doped HAP might have advantageous applications as bone and tooth materials.
\end{abstract}

Keywords: hydroxyapatite, silicon doped HAP, elements release, simulated body fluid

a INCDO INOE 2000, Research Institute for Analytical Instrumentation, 67 Donath str., RO400293, Cluj-Napoca, Romania

b Babeş-Bolyai University, Faculty of Chemistry and Chemical Engineering, 11 Arany Janos str., RO-400028, Cluj-Napoca, Romania

c Iuliu Hatieganu University of Medicine and Pharmacy, Orthopedics and Traumatology Department, 47 Traian Mosoiu Str., RO-400132 Cluj-Napoca, Romania

d Academy of Romanian Scientists, 54 Splaiul Independentei, RO-050094 Bucharest, Romania

*Corresponding author: mcotisel@chem.ubbcluj.ro 
O. CADAR, P.T. FRANGOPOL, G. TOMOAIA, D. OLTEAN, G.A. PALTINEAN, AURORA MOCANU, O. HOROVITZ, M. TOMOAIA-COTISEL

\section{INTRODUCTION}

Silicon is shown to be an essential element in biological bone growth and development [1]. Therefore, silicon substituted hydroxyapatites (HAP-Si) are a promising biomaterial for bone grafting [2, 3], and different methods were proposed in order to synthesize and characterize them from chemical, physical and biological point of view [3-7]. The role of HAP-Si based biomaterials in bone formation, mineralization and remodeling, by stimulation of human osteoblasts bioactivity and promotion of bone regeneration is approached by numerous investigations, both in vitro and in vivo [3, 7-13].

Silicon may enter in the hydroxyapatite, $\mathrm{Ca}_{10}\left(\mathrm{PO}_{4}\right)_{6}(\mathrm{OH})_{2}(\mathrm{HAP})$ lattice as silicate ions, $\mathrm{SiO}_{4}{ }^{4}$, substituting phosphate ions, $\mathrm{PO}_{4}{ }^{3-}$, but for the conservation of electroneutrality, some of the $\mathrm{OH}^{-}$ions should be eliminated, leading to the formula $\mathrm{Ca}_{10}\left(\mathrm{PO}_{4}\right)_{6-x}\left(\mathrm{SiO}_{4}\right)_{\times}(\mathrm{OH})_{2-x}$. Obviously, $x$ should remain less than 2; for $x=2$ the maximum theoretically possible Si content in HAP-Si would be $5.8 \mathrm{wt} \%$. But because of lattice distortions, the real limit should be lower, e.g. $5 \mathrm{wt} \%(x=1.7)[14,15], 4.35 \mathrm{wt} \%(x=1.5)[16], 4 \mathrm{wt} \%(x=1.4)[17,18]$, $3.1 \mathrm{wt} \%(\mathrm{x}=1.1)$ [19]. But silicon can also be present as $\mathrm{SiO}_{2}$, crystallized as quartz or as amorphous silica. There are authors suggesting the optimal bioctivity of HAP-Si to be attained for $0.8 \mathrm{wt} \% \mathrm{Si}(\mathrm{x}=0.28)[13,20,21]$, but also for $0.47 \%$ and $2.34 \% \mathrm{Si}$ an enhanced adhesion and proliferation of osteoblasts was observed [3].

In order to achieve its biological effect, HAP-Si has to release the necessary elements in the biological medium. For osteoblast activity and new bone tissue formation and development a continuous supply of elements is essential [22]. This is why in the present article we investigate the behavior of HAP-Si samples as compared with HAP in presence of water and simulated body fluid for a long time (90 days).

\section{RESULTS AND DISCUSSION}

Two silicon containing hydroxyapatites (HAP-Si) were prepared and compared with pure hydroxyapatite (HAP). Their composition is given in Table 1. The theoretical formulas where calculated assuming the entire amount of $\mathrm{Si}$ to be included in $\mathrm{SiO}_{4}{ }^{4-}$, which partially substitutes $\mathrm{PO}_{4}{ }^{3-}$ ions. 
Table 1. Composition of HAP and HAP-Si

\begin{tabular}{|l|c|c|l|l|}
\hline \multirow{2}{*}{ Name } & \multicolumn{3}{|c|}{ Composition (wt\%) } & \multirow{2}{*}{ Theoretical formula } \\
\cline { 2 - 4 } & $\mathrm{Ca}$ & $\mathrm{P}$ & \multicolumn{1}{|c|}{$\mathrm{Si}$} & \\
\hline HAP & 39.89 & 18.50 & 0 & $\mathrm{Ca} 10\left(\mathrm{PO}_{4}\right)_{6}(\mathrm{OH})_{2}$ \\
HAP-Si0.47 & 40.03 & 18.04 & 0.47 & $\left.\mathrm{Ca}_{10} \mathrm{PO}_{4}\right)_{5.83}\left(\mathrm{SiO}_{4}\right)_{0.17}(\mathrm{OH})_{1.83}$ \\
HAP-Si2.34 & 40.56 & 16.22 & 2.34 & $\left.\mathrm{Ca}_{10} \mathrm{PO}_{4}\right)_{5.18}\left(\mathrm{SiO}_{4}\right)_{0.82}(\mathrm{OH})_{1.18}$ \\
\hline
\end{tabular}

In order to identify the crystalline phosphate species present, the XRD spectra of the three samples were compared with Powder Diffraction Files (PDF) for pure hydroxyapatite (HAP) and pure $\beta$-calcium phosphate (TCP). As an example, the spectrum of the sample containing $0.47 \% \mathrm{Si}$ is compared with the PDF no. 09-0432 for stoichiometric HAP in Fig. 1a. HAP was the only phase identified in the pure hydroxyapatite sample and in HAP-Si0.47, while in HAP-Si2.34 a content of $83.6 \%$ HAP and $16.4 \% \beta$-TCP was estimated. Thus, the increasing Si content favours the conversion of HAP to $\beta$-TCP, as observed also in literature [4, 23-25]. No quartz phase was identified in the XRD patterns, but this fact does not exclude the presence of amorphous silica $\left(\mathrm{SiO}_{2}\right)$.

From the breadth of the peaks as compared to the XRD pattern of crystalline HAP taken as etalon, it is evident that all samples present a nanocrystalline structure. The average size of crystallites was calculated from the Debye-Scherrer relation. The estimated size of the crystallites in the samples is about $47 \mathrm{~nm}$ for HAP, $23 \mathrm{~nm}$ for HAP-Si0.47 and $25 \mathrm{~nm}$ for HAP$\mathrm{Si}$.34. The crystallinity degree of the samples, also estimated from the XRD patterns, was about $40-50 \%$ for all the samples.

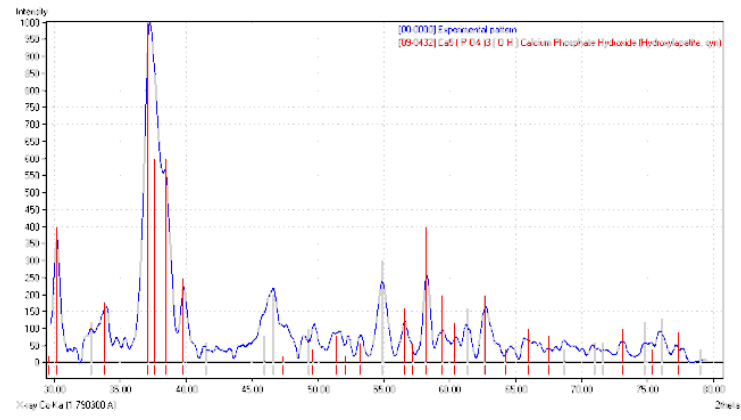

a

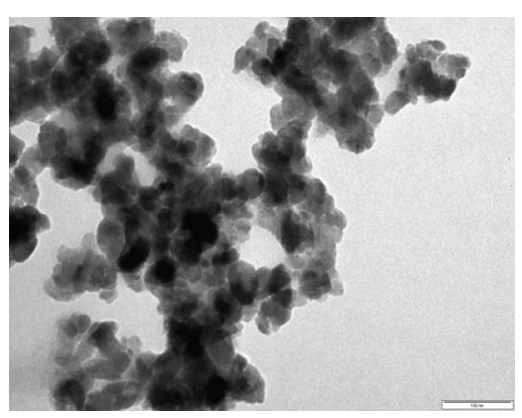

b

Figure 1. XRD patterns (a) for HAP-Si(.47 and the PDF no. 09-0432 file for stoichiometric HAP. (b) TEM image of a HAP-Si2.34 sample; bar length is $100 \mathrm{~nm}$. 
As an example, a TEM image for HAP-Si 2.34 is given in Fig. $1 b$. From TEM images the sizes of several hundreds of particles were measured, and the mean particle diameter was found to be about $26.5 \pm 5.2 \mathrm{~nm}$, with sizes between 16 and $42 \mathrm{~nm}$. The mean value is in substantial agreement with the particle diameter estimated from $\mathrm{X}$-ray diffraction.

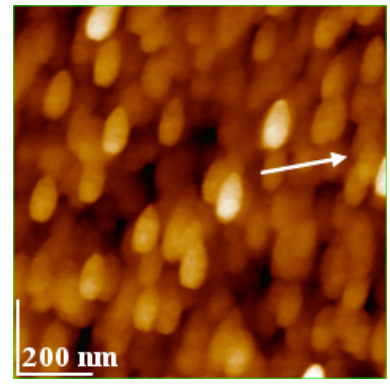

a

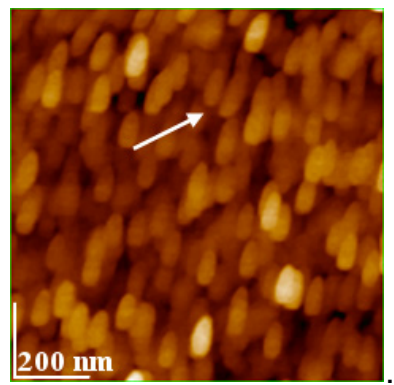

C

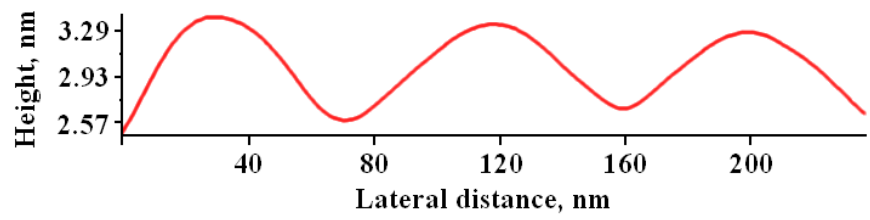

b

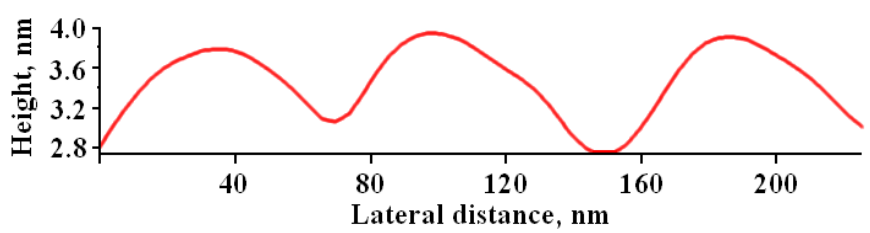

d

Figure 2. AFM images 2D-topography (ac) and cross section profile (b, d) along the arrows in pannel (a) and (c) respectively, for HAP-Si $0.47(\mathrm{a}, \mathrm{b})$ and HAP--Si2.34; scanned areas: $1 \mu \mathrm{m} \times 1 \mu \mathrm{m}$; surface roughness, RMS, on area $1.00 \mathrm{~nm}(\mathrm{a})$ and $0.90 \mathrm{~nm}(\mathrm{c})$; RMS profile $0.34 \mathrm{~nm}(\mathrm{~b}), 0.24 \mathrm{~nm}$ (d).

AFM images (Figure 2) also confirmed for HAP-Si powders the average size of particles in the nanoscale range, as following $42 \pm 3 \mathrm{~nm}$ for HAP-Si 0.47, and $45 \pm 4 \mathrm{~nm}$ for HAP-Si2.34. Thus, AFM images indicated that the nano suspensions of HAP-Si powders are formed of particles of almost identical size in good agreement with TEM values. 


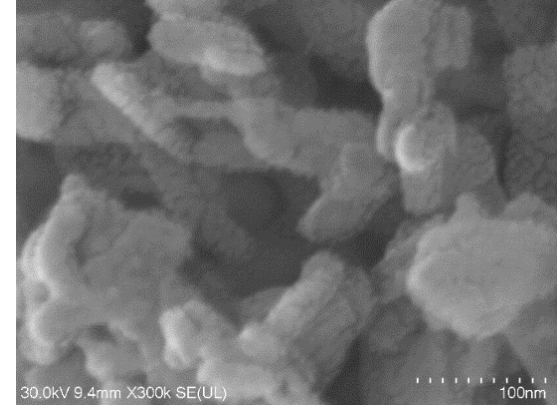

a

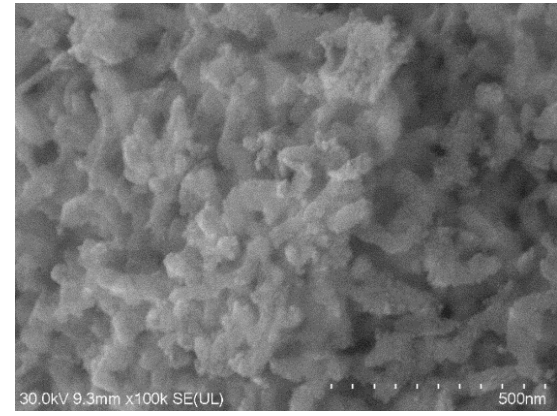

C

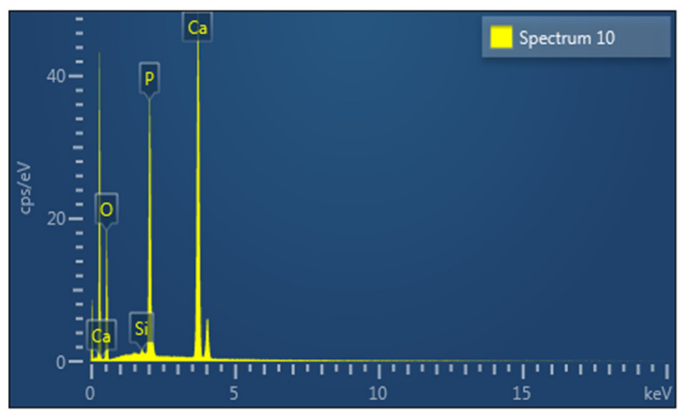

b

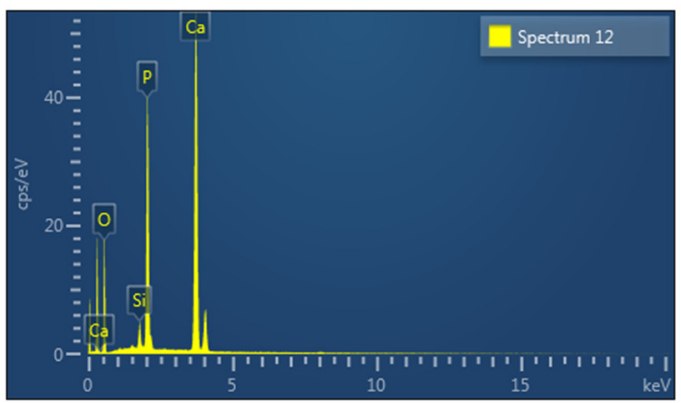

d

Figure 3. SEM image (a) and EDX spectrum (b) of HAP-Si0.47; SEM image (c) and EDX spectrum (d) of HAP-Si2.34. Bar length: $100 \mathrm{~nm}$ (a), and $500 \mathrm{~nm}$ (c) Examples of SEM images are given in Fig.3 for the HAP-Si0.47 and HAP-Si2.34, along with EDX spectra, which confirm the presence of $\mathrm{Si}$, together with $\mathrm{Ca}$ and $\mathrm{P}$ in both samples.

The FTIR spectrum of the HAP-Si0.47 sample is presented in Fig. 4a. The IR spectra of the HAP-Si samples are very similar to each other. Like the HAP sample, they present the characteristic peaks of the $\mathrm{PO}_{4}$ group: stretching vibrations: $v_{3}$ at $1032-1033$ and $1089-1091 \mathrm{~cm}^{-1} ; v_{1}$ at $962 \mathrm{~cm}^{-1}$; bending vibrations: $v_{4}$ at 565 and $602-603 \mathrm{~cm}^{-1} ; v_{2}$ at $473 \mathrm{~cm}^{-1}$ and of the structural $\mathrm{OH}$ (stretching at $3571-3572 \mathrm{~cm}^{-1}$ and libration at $633 \mathrm{~cm}^{-1}$. The last reduced to a shoulder in HAP-Si2.34 (Fig. 4b) as a consequence of the diminution of the $\mathrm{OH}$ groups in HAP by the substitution of phosphate by silicate ions. Peaks for absorbed water are visible at $3420-3440$ and $1637 \mathrm{~cm}^{-1}$. Peaks for the $\mathrm{SiO}_{4}$ group have their frequencies very near to those of $\mathrm{PO}_{4}$, and are therefore not observable. Nor can be detected vibrations characteristic for Si-O-Si bridges from silica [27, 28], and this could be an argument against the presence of free $\mathrm{SiO}_{2}$ in the HAP-Si samples. 


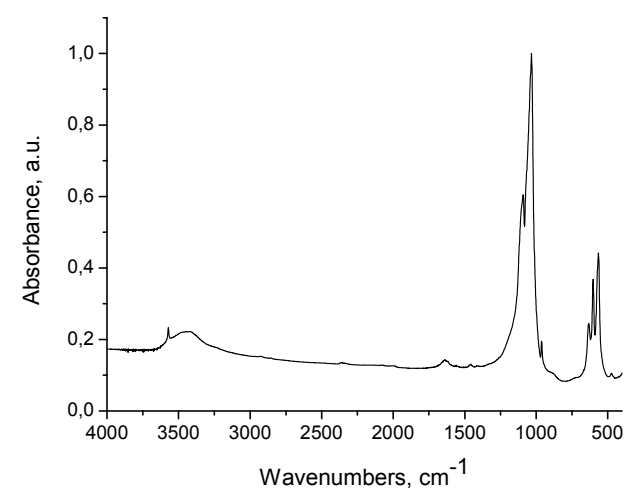

a.

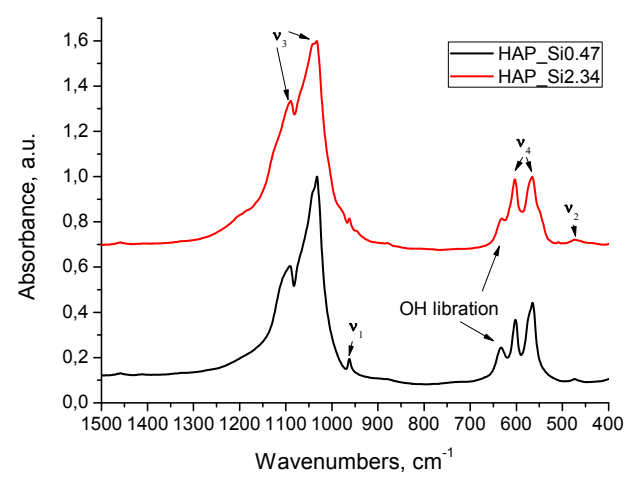

b.

Figure 4. FTIR spectrum for HAP-Si0.47 (a) and comparison between FTIR spectra for HAP__Si samples (detail) (b).

The $\mathrm{Ca}, \mathrm{P}$, and Si contents in the solution resulted after contact of the samples with ultrapure water, for $1,3,7,14.21,30,60$, and 90 days are presented graphically in Fig. $5 \mathrm{a}, \mathrm{b}$ and $\mathrm{c}$ respectively.

Pure HAP has a very low solubility in water; its solubility product

$$
\mathrm{K}_{\mathrm{sp}}=\left[\mathrm{Ca}^{2+}\right]^{10}\left[\mathrm{PO}_{4}^{3-}\right]^{6}\left[\mathrm{OH}^{-}\right]^{2}
$$

is very difficult to assess, and values in literature vary between $10^{-114}$ and $10^{-120}$ [29]; an international standard [30] recommends the value $(4.12 \pm 0.16) \cdot 10^{-118}$. Therefore, the $\mathrm{Ca}$ and $\mathrm{P}$ content in the aqueous solution in contact with the HAP sample is very low and nearly constant in time (Fig 5a, b). The Ca/P ratio in the solution is different from that in the solid because of the incongruent (nonstoichiometrical) solubility of HAP in water [29, 31, 32]. There is not a simple dissolution process, but a series of complex chemical reactions, with the formation of different calcium phosphate phases as surface coats [33, 34]. In the solution, $\mathrm{P}$ appears mainly as $\mathrm{HPO}_{4}{ }^{2-}$ ions, the predominant form at nearly neutral $\mathrm{pH}$. 


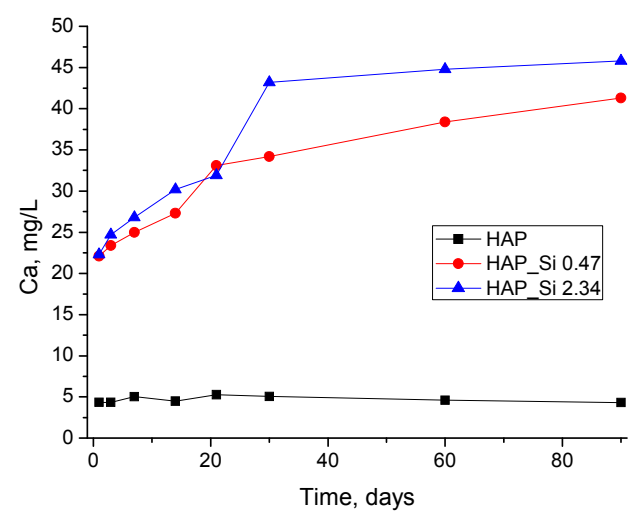

a.

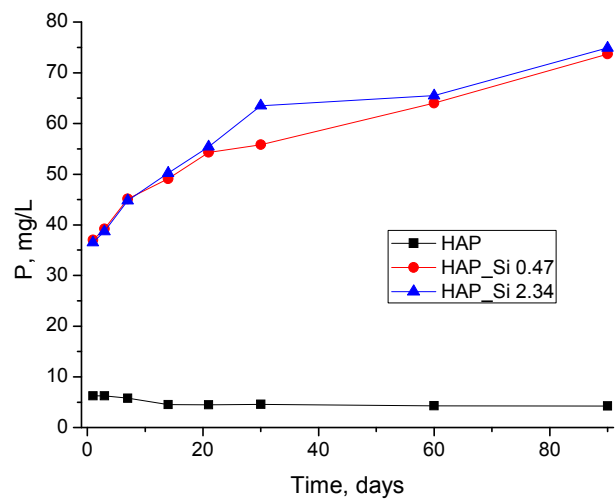

b

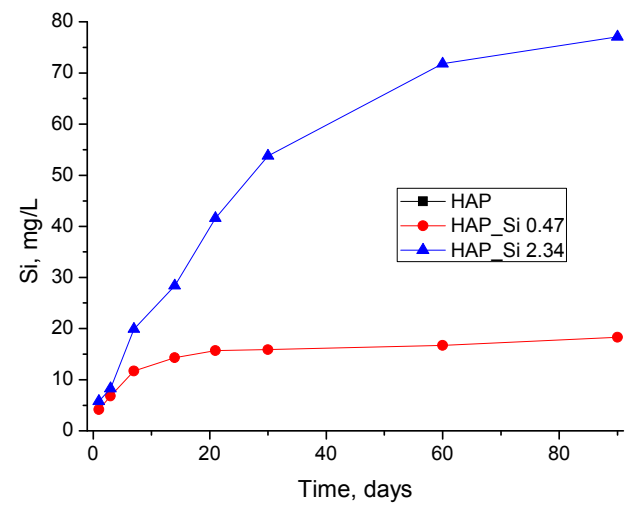

C.

Figure 5. $\mathrm{Ca}(\mathrm{a}), \mathrm{P}(\mathrm{b})$ and $\mathrm{Si}(\mathrm{c})$ release from HAP and HAP-Si samples in water

The presence of Si dramatically enhances both the $\mathrm{Ca}$ and $\mathrm{P}$ release, therefore it increases the solubility of the calcium phosphate, and the amount released increases continuously in time. Such an augmentation of the HAP solubility due to the presence of Si was observed both in vivo [12], and in vitro $[9,22,25,26]$. This ion release over a long period of time is important for the biomedical applications of substituted apatites, since this continuous supply of elements is essential for osteoblast activity and new bone tissue formation and development [22]. Based on HR-TEM results, it was suggested that an increased number of defects in the HAP-Si lattice causes the increase of calcium, phosphate and silicate ions release in the solution [12] The Si release also is increasing in time, especially for the HAP-Si2.34 sample. The values 
O. CADAR, P.T. FRANGOPOL, G. TOMOAIA, D. OLTEAN, G.A. PALTINEAN, AURORA MOCANU, O. HOROVITZ, M. TOMOAIA-COTISEL

of $\mathrm{Si} / \mathrm{Ca}$ and $\mathrm{Si} / \mathrm{P}$ ratios in the solution are much higher than in the solid, thus there is much more $\mathrm{Si}$ in the solution than expected from a congruent dissolution of HAP-Si. Probably not only the silicate ions in the crystals are released, but also $\mathrm{Si}$ from amorphous silica in the sample.

The elements contents $(\mathrm{Ca}, \mathrm{P}, \mathrm{Mg})$ in pure SBF are compared with those in SBF in presence of the samples for immersion times from 1 to 90 days in Fig. 6 a-c, while the variation in time of the Si content in the solution in contact with HAP-Si samples is shown in Fig. $6 \mathrm{~d}$.

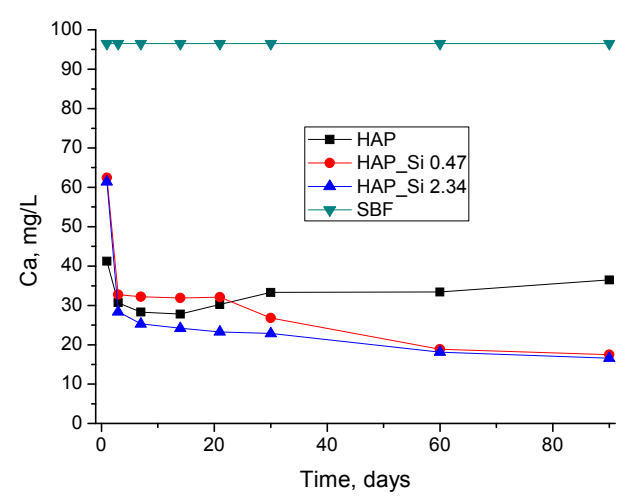

a.

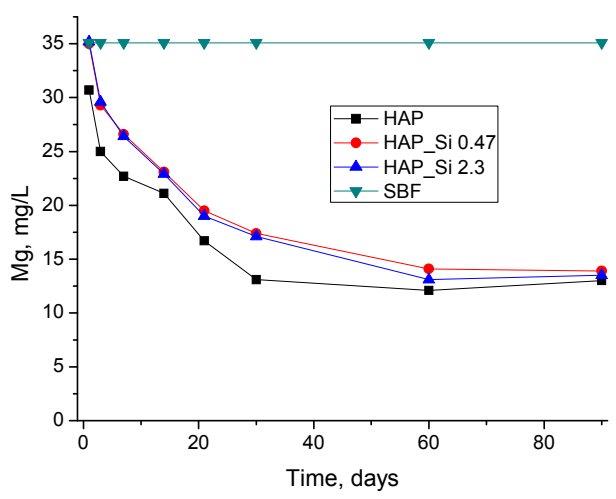

c.

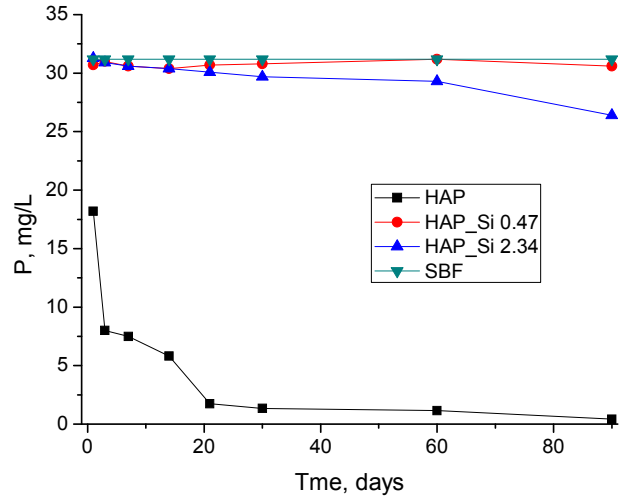

b.

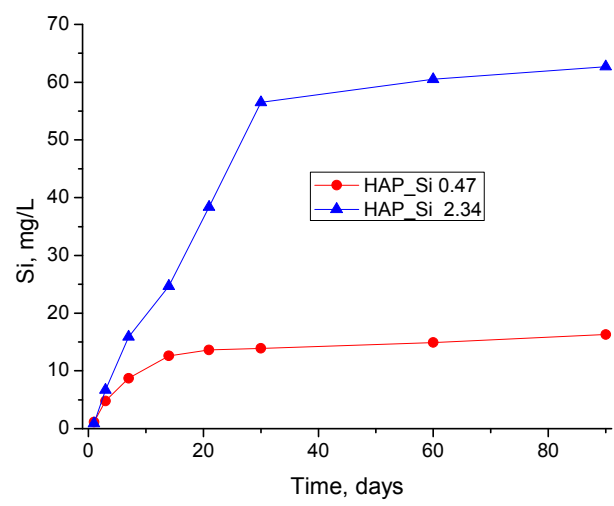

d.

Figure.6. $\mathrm{Ca}(\mathrm{a}), \mathrm{P}(\mathrm{b}), \mathrm{Mg}(\mathrm{c})$ and $\mathrm{Si}(\mathrm{d})$ content in SBF in absence and in presence of the HAP and HAP-Si samples. 
In SBF the $\mathrm{Ca}^{2+}$ concentration in presence of HAP is decreasing in time from its initial value in SBF $(96.5 \pm 0.5 \mathrm{mg} / \mathrm{L})$ as seen in Fig. 6a. The diminution is rapid in the first 30 days, then it is much slower, and even a slight increase is observed. It can be explained by uptake of $\mathrm{Ca}^{2+}$ along with $\mathrm{PO}_{4}{ }^{3-}$ ions from SBF for the building of new sold HAP and/or the sorption of $\mathrm{Ca}^{2+}$ in the HAP lattice, which are partially counterbalanced by the release of $\mathrm{Ca}^{2+}$ ions from the HAP lattice and/or the ion exchange with $\mathrm{Mg}^{2+}$ ions from the SBF solution, leading to new HAP enriched in Mg.

The decrease of the $P$ content in the SBF, from the initial value $(31.2 \pm 1.3 \mathrm{mg} / \mathrm{L})$ is more pronounced, and continues down to its near consumption from the solution (Fig. 6b). In the HAP-Si samples, this P uptake is compensated by the increased release of $\mathrm{P}$ due to the enhanced dissolution of the HAP-Si.

There is also a decrease in the $\mathrm{Mg}^{2+}$ content (Fig. 6c) of the SBF, from its initial value $(35.1 \pm 3.6 \mathrm{mg} / \mathrm{L})$, probably due to the ion exchange with $\mathrm{Ca}^{2+}$ from HAP and formation of Mg substituted HAP.

The Si release in SBF shows the same trends as in water, but the released amount is somewhat diminished. It was signalled in literature that the simultaneous presence of $\mathrm{Mg}$ and $\mathrm{Si}$ diminishes the elements release [22]. This could suggest the formation of complexes containing these two ions, more strongly bound to the HA crystal structure or to its amorphous part [22]. The excess of $\mathrm{Ca}^{2+}$ ions in SBF could also downgrade the dissolution equilibrium of HAP-Si. The Si content in the solution was larger for higher $\mathrm{Si}$ content in the HAP-Si.

In histological studies, an increase in the rate of bone apposition to HAPs implants by the substitution of silicate ions into HAP has been observed [12]. This higher bioactivity of HAP-Si was assigned to the effect of the accelerated dissolution caused by the silicate ions.

\section{CONCLUSIONS}

HAP and silicon substituted HAPs (0.47 and $2.34 \mathrm{wt} \% \mathrm{Si}$ ) were prepared by wet precipitation method. XRD investigations showed the presence of the HAP lattice as single phase present in HAP and HAP-Si0.47, and as majoritary phase in HAP-Si2.34. They possess nanostructure and a medium crystallinity degree. The HAP structure was confirmed by FTIR spectroscopy and the particles were visualized by TEM, AFM and SEM imaging. The elements release in water was much higher in HAP-Si than in pure HAP and continued till the end of the experiments. This long lasting elements release is an important premise for biomedical use of HAP-Si based biomaterials. 
The behavior of the samples in SBF could be explained in terms of $\mathrm{Ca}, \mathrm{P}$ and Mg uptake in the new HAP lattice and/or ion exchange, with a precipitation of HAP enriched in magnesium. The Si release showed a similar responsive behavior of HAP-Si, both in water and in SBF. Also, the increased $\mathrm{Si}$ concentration in HAP-Si significantly influenced the Si release in both media. Therefore, silicate ions have an important role in the structure of HAP-Si and might simultaneously bring physiological effects as a result of Si release.

\section{EXPERIMENTAL SECTION}

The nanostructured phosphates were prepared by the precipitation method previously developed by us for the synthesis of HAP and substituted HAPs [3, 35-38]. Briefly, HAP was obtained by rapidly mixing, at room temperature, equal volumes of $0.15 \mathrm{M}$ calcium nitrate solution $\left[\mathrm{Ca}\left(\mathrm{NO}_{3}\right)_{2} \cdot 4 \mathrm{H}_{2} \mathrm{O}\right.$ from Merck] and $0.09 \mathrm{M}$ diammonium phosphate solution $\left[\left(\mathrm{NH}_{4}\right)_{2} \mathrm{HPO}_{4}\right.$ from Sigma-Aldrich] at $\mathrm{pH} 11.5$ (settled by adding a 25\% ammonia solution). The maturation of the obtained suspension was achieved by maintaining it for 24 $\mathrm{h}$ at $22^{\circ} \mathrm{C}$, and for another $24 \mathrm{~h}$ at $70^{\circ} \mathrm{C}$, in a reactor, under intermittent stirring. The so obtained precipitate was filtered and washed repeatedly with ultrapure water until nitrate free. It was dried by lyophilization, then calcined at $300^{\circ} \mathrm{C}$ for one hour and disintegrated in a ball mill.

For the preparation of HAP-Si samples [3], in each solution nonylphenol was added (this surfactant helping to control nucleation and growth of nuclei). Sodium silicate $\left(\mathrm{Na}_{2} \mathrm{O}: \mathrm{SiO}_{2}=1: 3.2\right)$ was introduced in the phosphate solution in amounts calculated for the respective Si content in the final product. The $\mathrm{pH}$ of both solutions was adjusted to 11 , using ammonia solution. The solutions were fast mixed.at $60^{\circ}$, and the maturation was achieved at $80^{\circ} \mathrm{C}$ for $48 \mathrm{~h}$. After filtration, washing and lyophilisation the samples were calcined at $650{ }^{\circ} \mathrm{C}$ for 6-8 h.

The $X$-rays diffraction (XRD) patterns were investigated with a DRON3 diffractometer, in Bragg-Brentano geometry, using a X-ray tube with cobalt target ( $\mathrm{K}_{\alpha}$ line, wavelength $\left.1.79030 \AA\right)$.

FTIR spectra were measured on $\mathrm{KBr}$ pellets, containing the samples powders with a spectrometer JASCO 6100 in the $4000-400 \mathrm{~cm}^{-1}$ range of wave numbers, with a $2 \mathrm{~cm}^{-1}$ resolution.

Transmission electron microscope: TEM JEOL -JEM 1010 was used to determine the shape and the size of the phosphates nanoparticles. The samples were dispersed in deionized water, and the resulted colloidal dispersion was adsorbed on the TEM grids. 
For the examination with the scanning electron microscope SEM JEOL 5600 LV (backscattered-electron imaging technique, BSE), the samples were deposited as an uniform layer an adhesive graphitized tape. For local elemental analysis of different samples the energy-dispersive X-ray (EDX) spectroscopy was used coupled with SEM imaging.

Atomic force microscopy (AFM) images were obtained using the AFM JEOL 4210 equipment, operated in tapping mode [39-48], using standard cantilevers with silicon nitride tips (resonant frequency in the range of 200-300 $\mathrm{kHz}$, and spring constant $17.5 \mathrm{~N} / \mathrm{m}$ ). The particles were adsorbed from their aqueous dispersion for $20 \mathrm{~s}$ on optically polished glass support.

Elements release tests: The $\mathrm{Ca}, \mathrm{P}, \mathrm{Si}$ and $\mathrm{Mg}$ amounts were measured in the solutions after immersion of $0.15 \mathrm{~g}$ of each sample in $15 \mathrm{~mL}$ ultrapure water, respectively Kokubo simulated body fluid (SBF) and incubation $37^{\circ} \mathrm{C}$ in separated closed flasks for each sample/day. SBF solutions were prepared according to Kokubo's SBF solution [49], containing the following ions $\left(\mathrm{mmol} / \mathrm{dm}^{3}\right)$ : $\mathrm{Na}^{+}$(142.0); $\mathrm{K}^{+}$(5.0); $\mathrm{Mg}^{2+}$ (1.5); $\mathrm{Ca}^{2+}$ (2.5); $\mathrm{Cl}^{-}$(147.8); $\mathrm{HCO}_{3}{ }^{-}$(4.2); $\mathrm{HPO}_{4}{ }^{2-}$ (1.0); $\mathrm{SO}_{4}{ }^{2-}(0.5)$, and buffered at the physiologic $\mathrm{pH} 7.40$ at $37{ }^{\circ} \mathrm{C}$, with tris(hydroxymethyl)amino methane and hydrochloric acid.

After 1, 3, 7, 14, 21, 30, 60, and 90 days, the supernatant (after centrifugation) was filtered through $0.45 \mu \mathrm{m}$ paper filter $\mathrm{Ca}, \mathrm{Mg}, \mathrm{P}$ and $\mathrm{Si}$ contents were determined using an inductively coupled plasma optical emission spectrometer (ICP-OES) OPTIMA 3500 DV (Perkin-Elmer, USA) . For calibration, multi-element standard solutions were prepared by the dilution of stock multi-element $1000 \mathrm{mg} / \mathrm{L}$ solutions Merck IV $(0,0.1,0.5,1,2$, 4, 6, 8 and $10 \mathrm{mg} / \mathrm{L})$.

All the experiments were performed in triplicate and the results were calculated as average values. The elements content in SBF solution without samples was also measured in the same days, and the average value was calculated.

\section{ACKNOWLEDGMENTS}

The authors gratefully acknowledge the financial support from the Executive Agency for Higher Education, Research, Development and Innovation Funding (UEFISCDI) through grants no. 241 and no. no. 83. 
O. CADAR, P.T. FRANGOPOL, G. TOMOAIA, D. OLTEAN, G.A. PALTINEAN, AURORA MOCANU, O. HOROVITZ, M. TOMOAIA-COTISEL

\section{REFERENCES}

1. E.M. Carlisle, Calcified Tissue International, 1981, 33, 27.

2. W. Waked, J. Grauer, Orthopaedics, 2008, 31, 591.

3. Gh. Tomoaia, A. Mocanu, I. Vida-Simiti, N. Jumate, L.-D. Bobos, O. Soritau, M. Tomoaia-Cotisel, Materials Science and Engineering C, 2014, 37, 37.

4. I.R. Gibson, S.M. Best, W. Bonfield, Journal of Biomedical Materials Research, $1999,44,422$.

5. T. Leventouri, C.E. Bunaciu, V. Perdikatsis, Biomaterials, 2003, 24, 4205.

6. C.M. Botelho, M.A. Lopes, I.R. Gibson, S.M. Best, J.D. Santos, Journal of Material Science: Materals in Medicine, 2002, 13, 1123.

7. Z.Y. Qiu, I.S. Noh, S.M. Zhang, Frontiers of Materials Science, 2013, 7, 40.

8. A.F. Khan, M. Saleem, A. Afzal, A. Ali, A. Khan, A.R. Khan, Materials Science and Engineering $C, 2014,35,245$.

9. F. Balas, J. Pérez-Pariente, M. Vallet-Regí, Journal of Biomedical Materials Research, 2003, 66, 364.

10. A.E. Porter, N. Patel, J.N. Skepper, S.M. Best, W. Bonfield, Biomaterials, 2003, 24, 4609.

11. A.E. Porter, N. Patel, J.N. Skepper, S.M. Best, W. Bonfield, Biomaterials, 2004, 25, 3303.

12. A.E. Porter, C.M. Botelho, M.A. Lopes, J.D. Santos, S.M. Best, W. Bonfield, Journal of Biomedical Materials Research, 2004, 69A, 670.

13. K.A. Hing, P.A. Revell, N. Smith, T. Buckland, Biomaterials, 2006, 27, 5014.

14. E.S. Thian, J. Huang, M.E. Vickers, S.M. Best, Z.H. Barber, W. Bonfield, Journal of Materials Science, 2006; 41, 709.

15. M. Vallet-Regí, D. Arcos, Journal of Materials Chemistry, 2005, 15, 1523.

16. D. Marchat, M. Zymelka, C. Coelho, L. Gremillard, L. Joly-Pottuz, F. Babonneau, C. Esnouf, J. Chevalier, D. Bernache-Assollant, Acta Materialia, 2013, 9, 6992

17. G. Gasquères, C. Bonhomme, J. Maquet, F. Babonneau, S. Hayakawa, T. Kanaya, A. Osaka, Magnetic Resonance in Chemistry, 2008, 46, 342.

18. X.L. Tang, X.F. Xiao, R.F. Liu, Materials Letters, 2005, 59, 3841.

19. S. Gomes, J.M. Nedelec, E. Jallot, D. Sheptyakov, G. Renaudin, Crystal Growth and Design, 2011, 11, 4017.

20. .S.M. Best, S. Zou, R.A. Brooks, J. Huang, N. Rushton, W. Bonfield, Key Engineering Materials, 2008, 361-363, 985.

21. C.M. Bothelo, R.A. Brooks, S.M. Best, M.A. Lopes, J.D. Santos, N. Rushton, W. Bonfield, Journal of Biomedical Materials Research, 2006, 79A, 723.

22. S. Sprio, A. Tampieri, E. Landi, M. Sandri, S. Martorana, G. Celotti, G. Logroscino, Materials Science and Engineering C, 2008, 28, 179.

23. J.L. Xu, K.A. Khor, Journal of Inorganic Biochemistry, 2007, 101, 187. 
24. A.J. Ruys, Journal of the Australan Ceramic Society, 1993, $29,71$.

25. S.L. Seet, Science Asia, 2009, 35, 255.

26. D.M. Ibrahim, A.A. Mostafa, S. Ibrahim Korowash, Chemistry Central Journal, 2011, 5:74, $11 \mathrm{pp}$

27. M.A. Karakassides, D. Gournis, D. Petridis, Clay Minerals, 1999, 34, 429.

28. E.R. Lippincott, A. Van Valkenburg, C.E. Weir, E.N. Bunting, Journal of Research of the National Bureau of Standards, 1958, 61, 61.

29. H.W. Kaufman, I. Kleinberg, Calcified Tissue International, 1979, 27, 143.

30. ${ }^{* * *}$ International Standard ISO 13779-6 Implants for Surgery - Hydroxyapatite, Part 6: Powders, 2015.

31. A.N. Smith, A.M. Posner, J.P. Quirk, Journal of Colloid and Interface Science, 1974, 48, 442.

32. S.V. Dorozhkin, Journal of Colloid and Interface Science, 1997, 191, 489.

33. R.P. Shellis, F.K. Wahab, B.R. Heywood, Caries Research, 1993, 27, 365.

34. R.P. Shellis, B.R. Heywood, F.K. Wahab, Caries Research, 1997, 31, 71.

35. Gh. Tomoaia, M. Tomoaia-Cotisel, L.B. Pop, A. Pop, O. Horovitz, A. Mocanu, N. Jumate, L.-D. Bobos, Revue Roumaine de Chimie, 2011, 56, 1039.

36. Gh. Tomoaia, O. Soritau, M. Tomoaia-Cotisel, L.-B. Pop, A. Pop, A. Mocanu, O. Horovitz, L.D. Bobos, Powder Technology, 2013, 238, 99.

37. C. Garbo, M. Sindilaru, A. Carlea, G. Tomoaia, V. Almasan, I. Petean, A. Mocanu, O. Horovitz, M. Tomoaia-Cotisel, Particulate Science and Technology, 2017, 35, 29.

38. A. Mocanu, R. Balint, C. Garbo, L. Timis, I. Petean, O. Horovitz, M. TomoaiaCotisel, Studia Universitatis Babes-Bolyai, Chemia, 2017, 62(2), Tom I, 95.

39. M.A. Naghiu, M. Gorea, E. Mutch, F. Kristaly, M. Tomoaia-Cotisel, Journal of Material Science and Technology, 2013, 29(7), 628.

40. O. Horovitz, Gh. Tomoaia, A. Mocanu, T. Yupsanis, M. Tomoaia-Cotisel, Gold Bulletin, 2007, 40 (4), 295.

41. M. Tomoaia-Cotisel, A. Tomoaia-Cotisel, T. Yupsanis, G. Tomoaia, I. Balea, A. Mocanu, Cs. Racz, Revue Roumaine de Chimie, 2006, 51 (12),1181.

42. A. Danistean, M. Gorea, A. Avram, S. Rapuntean, Gh. Tomoaia, A. Mocanu, C. Garbo, O. Horovitz, M. Tomoaia-Cotisel, Studia Universitatis Babes-Bolyai, Chemia, 2016, 61 (3), 275.

43. Gh. Tomoaia, O. Horovitz, A. Mocanu, A. Nita, A. Avram, C.P. Racz, O. Soritau, M. Cenariu, M. Tomoaia-Cotisel, Colloids and Surfaces B: Biointerfaces, 2015, $135,726$.

44. P.T. Frangopol. D.A. Cadenhead, Gh. Tomoaia, A. Mocanu, M. Tomoaia-Cotisel, Revue Roumaine de Chimie, 2015, 60(2-3), 265.

45. G. Furtos, M.A. Naghiu, H. Declercq, M. Gorea, C. Prejmerean, O. Pana, M. Tomoaia-Cotisel, Journal of Biomedical Materials Research Part B. Applied Biomaterials, 2016, 104, 1290.

46. M. Tomoaia-Cotisel, A. Mocanu, Revista de Chimie (Bucharest), 2008, 59, 1230. 
O. CADAR, P.T. FRANGOPOL, G. TOMOAIA, D. OLTEAN, G.A. PALTINEAN, AURORA MOCANU, O. HOROVITZ, M. TOMOAIA-COTISEL

47. R.D. Pasca, G. Tomoaia, A. Mocanu, I. Petean, G.A. Paltinean, O. Soritau, M. Tomoaia-Cotisel, Studia Universitatis Babes-Bolyai, Chemia, 2015, 60(3), 257.

48. G. Tomoaia, A. Mocanu, L.D. Bobos, L.B. Pop, O. Horovitz, M. Tomoaia-Cotisel, Studia Universitatis. Babes-Bolyai, Chemia, 2015, 60 (3), 265.

49. T. Kokubo, H. Kushitani, S. Sakka, T. Kitsugi, T. Yamamuro, Journal of Biomedical Materials Research, 1990, 24, 721. 